\title{
Production of antioxidant compounds from tissue culture of Artemisia annua
}

\author{
AMALIA INDAH PRIHANTINI, ${ }^{1, \boldsymbol{v}}$, AGUS SUKITO ${ }^{1}$, SANRO TACHIBANA $^{2}$ \\ ${ }^{1}$ Forest Research and Development Agency (FORDA), Ministry of Forestry, Republic Indonesia. Manggala Wanabhakti Building, Jl. Jend. Gatot \\ Subroto, Jakarta, Indonesia, Tel.(+62-370-6175552, Fax.+62-370-6175482, •email: amaliaindah2@ gmail.com \\ ${ }^{2}$ Department of Applied Bioscience, Faculty of Agriculture, Ehime University. 3-5-7 Tarumi, Matsuyama, Ehime, 790-8566, Japan.
}

Manuscript received: 28 October 2017. Revision accepted: 2 November 2018.

\begin{abstract}
Prihantini AI, Sukito A, Tachibana S. 2018. Production of antioxidant compound from tissue culture of Artemisia annua. Nusantara Bioscience 10: 251-255. Phenolic compounds have attracted much attention because of their role in some oxidative diseases. Therefore, the study aimed to investigate the production of antioxidant compound from tissue culture of $A$. annua. The callus were developed on solid MS medium treated with four combination of plant growth regulators: NAA $0.5 \mathrm{mg} / \mathrm{L}+\mathrm{BA} 0.5 \mathrm{mg} / \mathrm{L}$; NAA 0.5 $\mathrm{mg} / \mathrm{L}+$ kinetin $0.5 \mathrm{mg} / \mathrm{L} ; 2,4-\mathrm{D} 0.5 \mathrm{mg} / \mathrm{L}+\mathrm{BA} 0.5 \mathrm{mg} / \mathrm{L}$; and 2,4-D $0.5 \mathrm{mg} / \mathrm{L}+$ kinetin $0.5 \mathrm{mg} / \mathrm{L}$. The callus extracts were evaluated their antioxidant activity and were analyzed the content of phenolic content. Furthermore, detection and quantification of phenolic compound were investigated. Combination of NAA $0.5 \mathrm{mg} / \mathrm{L}+\mathrm{BA} 0.5 \mathrm{mg} / \mathrm{L}$ showed the highest DPPH radical scavenging activity and total phenolic content. GCMS analysis also revealed that the combination also showed the highest content of caffeic acid, a phenolic compound known as an antioxidant agent. Furthermore, the callus extract treated with NAA $0.5 \mathrm{mg} / \mathrm{L}+\mathrm{BA} 0.5 \mathrm{mg} / \mathrm{L}$ increased both the antioxidant activity and caffeic acid content compared with $A$. апnиa leaf extract. In conclusion, plant tissue culture enhanced pharmaceutical properties of A. annua. Moreover, the study suggested that the treated callus extract of $A$. annua is potential to be further developed for production of antioxidant compound.
\end{abstract}

Keywords: Antioxidant, Artemisia апnиa, caffeic acid, plant growth regulator, tissue culture

Abbreviation: NAA: naphthalene acetic acid, BA: benzyl adenine, 2,4-D: 2,4-dichlorophenoxyacetic acid, DPPH: 1,1-diphenyl-2picrylhydrazyl, GCMS: gas chromatography-mass spectrometry

\section{INTRODUCTION}

Plant tissue culture is one of the potential methods, which is not only used for large-scale plant production but also secondary metabolites production, particularly in the pharmaceutical industry. Various chemical compounds such as polyphenols, alkaloids, saponins, carotenoids, anthocyanins, etc. had been successfully synthesized and accumulated using plant tissue culture. This method could also be used to improve the production of various secondary metabolites, which is naturally difficult to be produced in large amount in plants (Ali et al. 2013). Furthermore, it is an essential method for medicinal plant conservation particularly if plants contains the highly demanded metabolite compounds used for curing diseases (Moyo et al. 2011). In addition, the natural low content of secondary metabolites, physiological status, and developmental stages of plants cause high plant exploitation leading to the plant extinction in the future (Amoo et al. 2013). Therefore, the plant biotechnological approaches using tissue culture is of importance to conserve the medicinal plants as well as to increase their secondary metabolite production.

Artemisia belongs to a genus with groups of aromatic and medicinal plants. From the genus Artemisia, A. annua is one of the primary sources of drugs used in traditional and modern medicine (Jelodar et al. 2014). Furthermore, this plant has been recorded in the ethnopharmacological history of China, known as Chinese Materia Medica (Willcox et al. 2007). A. апnua is originated from China, which is mostly distributed in the temperate, cool temperate, subtropical zones and Mediterranean region (Ferreira and Janick, 1996). Although it is originated from subtropical region, A. аппиа can be cultivated in the tropical region with some treatments during breeding practices. Some tropical country had cultivated A. апnиa such as Malaysia, Brazil, Vietnam, and Madagascar (Laughlin 2002). A. апnиa has been easily adapted and grown in wide diversity of soils and latitudes. It is a shrub and usually single-stemmed about $2 \mathrm{~m}$ in height with alternate branches (Jelodar et al. 2014).

As medicinal plant, Artemisia annua produces a valuable antimalarial drug, known as artemisinin. Artemisinin can be extracted from leaves and tissue culture of A. апnua plant. Several kinds of research on the production and enhancement of artemisinin contents for antimalarial drug extracted from tissue culture have been successfully reported (Baraldi et al. 2008; Weathers et al. 2011; Keng et al. 2010; Mohammad et al. 2013; Ahlawat et al. 2014). Studies on other metabolites contained in $A$. annua leaves such as phenolic compounds used for medicinal drugs in pharmaceutical business have been also 
reported. There was forty type of phenolic compounds have been isolated from the leaves of $A$. аппиа i.e.: eight types of $C$-glycosyl flavonoids, five types of $O$-glycosyl flavonoids, three types of flavonoid aglycones, twenty-one types of quinic acid derivatives, two types of benzoic acid glucosides and a coumarin (Han et al. 2008).

Among different classes of secondary metabolites, polyphenols are the largest group of natural antioxidant (Cieśla et al. 2012). In particular, phenolics are considered to be effectively used for curing several diseases (Ibrahim et al. 2012). However, the study of phenolic compounds derived from tissue culture of A. annua is still limited. The use of similar method using tissue culture for the improvement of artemisinin production, may be also effectively adopted to enhance medicinally important phenolics of the A. апnua plant (Ali et al. 2013). The present study investigated the combination of different plant growth regulators to increase the production of phenolic compound from tissue culture of $A$. аnnua and analyzed their biological activities. Furthermore, the study was also analyzed the content of particular phenolic compound and bioactivities of the leaves of $A$ annua as comparison.

\section{MATERIALS AND METHODS}

\section{Callus induction of in vitro Artemisia annua Induction of callus}

The fresh leaves of $A$. апnиa were surface sterilized by washing with soap and tap water, soaking in $70 \%$ ethanol for 1 minute followed by $1 \%$ of sodium hypochlorite for 20 minutes. After rinsing with distilled water three times, the leaves were cut and placed in a glass containing Murashige and Skoog (MS) medium with the addition of 3\% of sucrose, $0.25 \%$ of gellan gum, $0.5 \mathrm{mg} / \mathrm{L}$ 6-benzyl adenine (BA) and $0.5 \mathrm{mg} / \mathrm{L}$ naphthaleneacetic acid (NAA) as plant growth regulators. The in vitro leaves were incubated in $25^{\circ} \mathrm{C}$ at dark condition for 5 weeks.

\section{Treatment of sub-culture}

The growing callus were sub cultured in a treatment of four different combinations of plant growth regulators (Figure 1). The combination of plant growth regulators was as follows: treatment $1(0.5 \mathrm{mg} / \mathrm{L} \mathrm{BA}+0.5 \mathrm{mg} / \mathrm{L} \mathrm{NAA})$; treatment $2(0.5 \mathrm{mg} / \mathrm{L}$ Kinetin $+0.5 \mathrm{mg} / \mathrm{L}$ NAA $)$; treatment $3(0.5 \mathrm{mg} / \mathrm{L} \mathrm{BA}+0.5 \mathrm{mg} / \mathrm{L}$ 2,4-dichlorophenoxyacetic acid $(2,4-\mathrm{D}))$; and treatment $4(0.5 \mathrm{mg} / \mathrm{L}$ Kinetin +0.5 $\mathrm{mg} / \mathrm{L}$ 2,4-D). The sub cultured callus were incubated in similar conditions of previous callus induction. The sub cultured callus were then dried, blended, and extracted with methanol to obtain crude extracts.

\section{Extraction of leaves}

The fresh leaves were collected, dried, and extracted with methanol. The leaf extract was concentrated using rotary evaporator and vacuum dried before was analyzed the detection of particular phenolic compound by GCMS and the evaluation of biological activities.

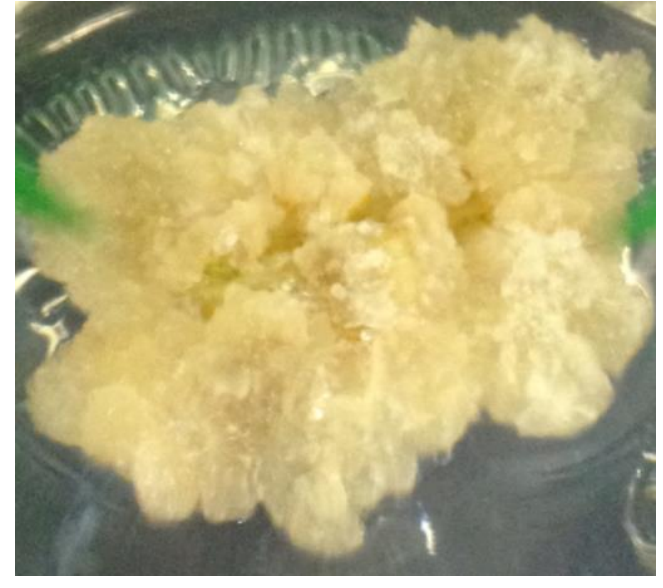

Figure 1. Callus development of Artemisia апnиа

\section{DPPH radical scavenging assay}

The callus and leaf extracts were evaluated their biological activity including DPPH radical scavenging activity assay, $\alpha$-glucosidase inhibitory activity, and total phenolic contents. The DPPH radicals scavenging activity was conducted based on a previous method (Jayaprakasha et al. 2001) with minor modifications. Various concentrations of samples were mixed with $0.5 \mathrm{~mL}$ of the 1 $\mathrm{mM}$ DPPH radical solution in methanol. A similar solution without a sample was used as control. Absorbance was measured using a UV-vis spectrophotometer at $517 \mathrm{~nm}$ after incubation at room temperature under dark condition for $30 \mathrm{~min}$. Quercetin was used as a positive standard.

\section{Quantification of phenolic compound}

The detection and quantification of phenolic compounds were conducted using GC-MS. Mass spectra were recorded using Shimadzu GC-MS QP 5050A (Shimadzu Corp.). The samples and standard were trimethylsilylated prior to GC-MS analysis. The ion fragmentations of samples were compared with the internal library in the instrument, which was then followed by comparing with chromatogram and ion fragmentations of the authentic standard. The specific phenolic peak was then quantified to the authentic standard.

\section{Data analysis}

All assays were performed in triplicate in independent three experiments. Data were expressed as the mean \pm standard deviation and analyzed by SPSS version 16.0 for Windows followed by Duncan's post-hoc test. Values with $P<0.05$ were considered as statistically significant.

\section{RESULTS AND DISCUSSION}

\section{Sub-cultured callus formation}

The growth of callus formation was relatively slow. The best result of callus biomass was shown in MS supplemented with combination of $0.5 \mathrm{mg} / \mathrm{L}$ NAA and 0.5 $\mathrm{mg} / \mathrm{L}$ Kinetin; and combination of $0.5 \mathrm{mg} / \mathrm{L}$ NAA and 0.5 $\mathrm{mg} / \mathrm{L}$ BAP, characterized by a higher dry weight, faster growth, and friable callus particularly (Table 1). The dry 
weight of those combinations of plant growth regulators was $5.01 \pm 0.23$ and $5.83 \pm 0.37 \mathrm{mg} / \mathrm{L}$, respectively. The addition of 2,4-D showed lower quantities of dry weight, slower growth, and compact callus compared with that of NAA supplementation.

Furthermore, the combination of $0.5 \mathrm{mg} / \mathrm{L} \mathrm{2,4-D}+0.5$ $\mathrm{mg} / \mathrm{L}$ Kinetin resulted in brownish callus performances. Meanwhile, the combination of $0.5 \mathrm{mg} / \mathrm{L} \mathrm{2,4-D} \mathrm{+} 0.5 \mathrm{mg} / \mathrm{L}$ Kinetin showed the slowest growth and the lowest biomass $(1.05 \pm 0.11 \mathrm{mg} / \mathrm{L})$ of all applied treatments. Therefore, the results suggested that NAA was more responsive than 2,4$\mathrm{D}$ as auxin for callus induction. Other studies also reported best callogenic response on combination of NAA and BA (Nin et al. 1997; Zia et al. 2007). Furthermore, kinetin showed slightly better performance than BA as cytokinin.

\section{Analysis of DPPH radical scavenging activity) in callus and leaf extracts}

DPPH or 1,1-diphenyl-2-picrylhydrazyl is a stable radical that is widely used to evaluate the activity of scavenging free radicals. DPPH scavenging activity assay was conducted to evaluate the antioxidant activity. The antioxidant effect was qualified by the discoloration of purple as an indicator of DPPH radical activities. Antioxidant molecules reduce radicals by donating hydrogen (El-Haci et al. 2013), which result in the colorless discoloration of stable molecule of 2,2-diphenyl1-hydrazine. Activities of DPPH radicals scavenging were depended on dose concentration, which could be observed from an $\mathrm{IC}_{50}$ value. This value indicated the required concentration to scavenge $50 \%$ of the free radicals.

DPPH radical scavenging activity of the callus and leaf extracts were investigated (Table 2). Treatment 1 showed the highest DPPH radical scavenging activity in callus extract followed by treatment 3,4 , and 2 with $\mathrm{IC}_{50}$ at $53.20 \pm 0.51,66.86 \pm 3.86,86.49 \pm 2.27$, and 99.15 \pm 10.81 , respectively. This DPPH radical scavenging activity amongst treatments was significantly different at $P<0.05$ using ANOVA analysis followed by Duncan's test. The result showed that the supplementation of cytokinin BA is also considered to give better effect on the accumulation of DPPH radicals scavenging activity in the callus of $A$. Annua compared to that of kinetin supplementation.

Table 1. The effect of different combination plant growth regulators on callus growth

\begin{tabular}{|c|c|c|c|c|}
\hline $\begin{array}{l}\text { Treat- } \\
\text { ments }\end{array}$ & $\begin{array}{c}\text { Combination of plant } \\
\text { growth regulators } \\
(\mathrm{mg} / \mathrm{L})\end{array}$ & $\begin{array}{c}\text { Callus } \\
\text { morphology }\end{array}$ & Growth & $\begin{array}{c}\text { Dry } \\
\text { weight } \\
(\mathrm{mg} / \mathrm{L}) \\
\end{array}$ \\
\hline 1 & NAA $0.5+$ BA 0.5 & $\begin{array}{l}\text { Yellowish, } \\
\text { friable }\end{array}$ & +++ & $5.01 \pm 0.23$ \\
\hline 2 & NAA 0.5 + Kinetin 0.5 & $\begin{array}{l}\text { Yellowish, } \\
\text { friable }\end{array}$ & +++ & $5.83 \pm 0.37$ \\
\hline 3 & 2,4-D $0.5+$ BA 0.5 & $\begin{array}{l}\text { Yellowish, } \\
\text { compact }\end{array}$ & + & $1.05 \pm 0.11$ \\
\hline 4 & 2,4-D $0.5+$ Kinetin 0.5 & $\begin{array}{l}\text { Brownish, } \\
\text { compact }\end{array}$ & ++ & $2.83 \pm 0.45$ \\
\hline
\end{tabular}

In leaf extracts, DPPH radical scavenging assay showed that leaf extract exhibited lower activity compare with callus extract particularly with that of treatment 1 and treatment 3. The treatments of callus increased the antioxidant activity of the direct plant. Their metabolism, composition of compounds, and interaction between compounds are considered affect the activity (Table 2). In general, treatment 1 with $0.5 \mathrm{mg} / \mathrm{L} \mathrm{NAA}+0.5 \mathrm{mg} / \mathrm{L} \mathrm{BA}$ was the best combination of plant growth regulators showing in the highest antioxidant activity among others. Moreover, cytokinin BA is considerable to give good effect on antioxidant activity contents. This means that tissue cultures of A. аnnua had higher antioxidant activities than the leaf extract. However, many other metabolite compounds may also contribute to antioxidant activity. This is consistent with the findings of several studies that other secondary metabolites such as vitamins, volatile oils, carotenoids, proteins, terpenoids, and alkaloids influence the antioxidant activity in plants (Basma et al. 2011; Hassimoto et al. 2005).

\section{Detection and quantification of phenolic compound in callus and leaf extracts}

The detection of phenolic compound existing in the callus and leaf extract was investigated. The highest total phenolic content was shown in treatment 1 followed by treatments 3,4 , and 2 with values at $147.98 \pm 6.58$; $106.88 \pm 8.45 ; 103.71 \pm 0.43$; and $60.80 \pm 3.98 \mathrm{mg} \mathrm{GAE} / \mathrm{g}$ dry extract, respectively (Table 3). The activity was significantly different amongst treatments at $P<0.05$ using a statistical analysis with ANOVA followed by Duncan's test. The total phenolic content in plant extracts is responsible to antioxidant and $\alpha$-glucosidase inhibitor activities.

Table 2. DPPH radical scavenging activity of callus extracts

\begin{tabular}{ccc}
\hline Extracts & $\begin{array}{c}\text { Combination of plant } \\
\text { growth regulators }(\mathbf{m g} / \mathbf{L})\end{array}$ & $\begin{array}{c}\mathbf{I C}_{\mathbf{5 0}} \mathbf{D P P H} \\
(\boldsymbol{\mu g} / \mathbf{m L})\end{array}$ \\
\hline Treatment 1 & NAA 0.5 + BA 0.5 & $53.20 \pm 0.51 \mathrm{a}$ \\
Treatment 2 & NAA 0.5 + Kinetin 0.5 & $99.15 \pm 10.81 \mathrm{~d}$ \\
Treatment 3 & 2,4-D 0.5 + BA 0.5 & $66.86 \pm 3.86 \mathrm{~b}$ \\
Treatment 4 & 2,4-D 0.5 + Kinetin 0.5 & $86.49 \pm 2.27 \mathrm{c}$ \\
Leaf extract & - & $96.65 \pm 1.23 \mathrm{~d}$ \\
\hline
\end{tabular}

Note: Data were expressed as mean \pm standard deviation values. Different letters in the same column indicated significant differences $(P<0.05)$.

Table 3. Total phenolic content of callus leaf extracts of A. annua

\begin{tabular}{lcc}
\hline Extract & $\begin{array}{c}\text { Combination of plant } \\
\text { growth regulators } \\
(\mathbf{m g} / \mathbf{L})\end{array}$ & $\begin{array}{c}\text { Total phenolic } \\
\text { content (mg GAE/g } \\
\text { dry extract) }\end{array}$ \\
\hline Treatment 1 & NAA 0.5 + BA 0.5 & $147.98 \pm 6.58 \mathrm{a}$ \\
Treatment 2 & NAA 0.5 + Kinetin 0.5 & $60.80 \pm 3.98 \mathrm{~d}$ \\
Treatment 3 & 2,4-D 0.5 + BA 0.5 & $106.88 \pm 8.45 \mathrm{~b}$ \\
Treatment 4 & 2,4-D 0.5 + Kinetin 0.5 & $103.71 \pm 0.43 \mathrm{c}$ \\
Leaf extract & - & $160.74 \pm 0.49 \mathrm{a}$ \\
\hline
\end{tabular}

Note: GAE = gallic acid equivalent 


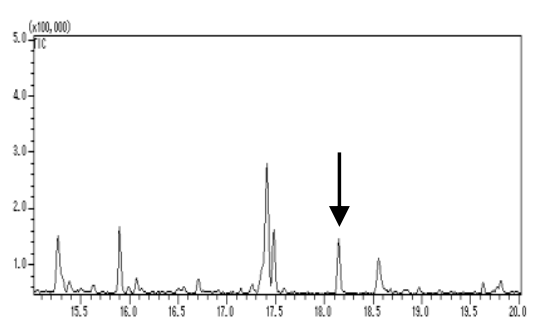

A

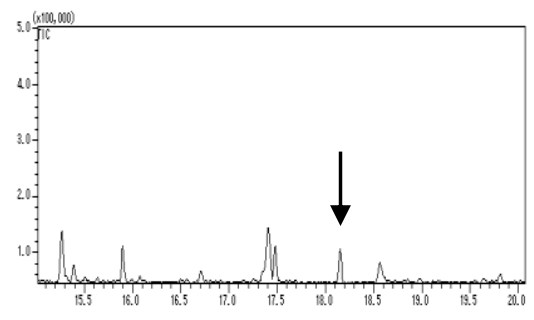

B

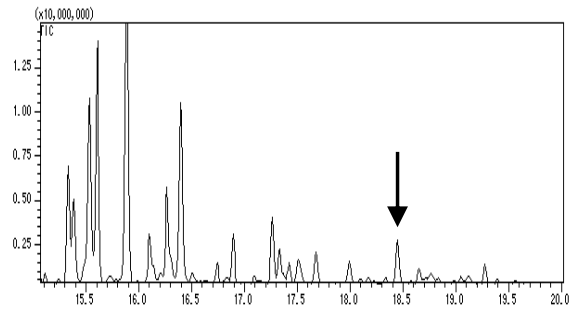

C

Figure 2. Chromatogram of callus extract of combination NAA $0.5+$ BA $0.5 \mathrm{mg} / \mathrm{L}$ (A), NAA $0.5+$ Kinetin $0.5 \mathrm{mg} / \mathrm{L}$ (B), and leaf extract (C)

The analysis using GCMS showed that caffeic acid as one of well-known antioxidant compounds was positively detected on treatments 1 and 2. Meanwhile, in treatment 3 and 4 , caffeic acid was not detected. The peaks of caffeic acid on treatment 1 and 2 were not a major peak. Other phenolic compounds such as gallic acid, methyl gallate, and catechin were not detected on all treatments. The profile of chromatogram and ion fragmentations of treatment 1 and 2 are shown in Figure 2.A and 2.B. The ion fragmentation of the peak detected in the chromatogram compared with caffeic standard using GC-MS equipped with SPB-50 column strongly indicated that caffeic acid was produced in the callus treatments 1 and 2 .

In leaf extracts derived from in vitro plantlets, the detection and quantification of phenolic compounds have also been investigated using GCMS equipped with TC-1 column (Figure 2.C). Since the leaf extract was analyzed using different column with callus extracts, the caffeic acid peak was slightly shifted. However, we also analyzed the authentic standard of caffeic acid with similar column and conditions and the result showed similar retention time with the caffeic acid peak detected on leaf extract. Moreover, similar to callus extract, the peak performance of caffeic acid in the leaf extract was not major and other phenolic compounds such as gallic acid, methyl gallate, and catechin were not detected. The low amount of caffeic acid in A. апnиa also have been reported by Suberu et al. (2014). The result showed that both on callus extract and leaf extract of $A$. аnnua showed a presence of caffeic acid.

The quantification of caffeic acid content showed that treatment 1 had higher peak than treatment 2 suggesting that treatment 1 had higher content of caffeic acid (Figure 3). It was considered that caffeic acid plays a role in antioxidant activity particularly in treatment 1 . The caffeic acid content of leaf extract of $A$. апnиa revealed that it contained $2.83 \pm 0.24 \mathrm{mg}$ caffeic acid/g dry extracts, lower than treatment 1 with $4.01 \pm 0.78 \mathrm{mg}$ caffeic acid $/ \mathrm{g}$ dry extracts, but higher than treatment 2 with $2.71 \pm 0.36 \mathrm{mg}$ caffeic acid/g dry extracts. The result indicated that callus treatment particularly treatment 1 increased the content of caffeic acid. Furthermore, it suggested that treatment 1 increased both the production of caffeic acid and the biological activities.

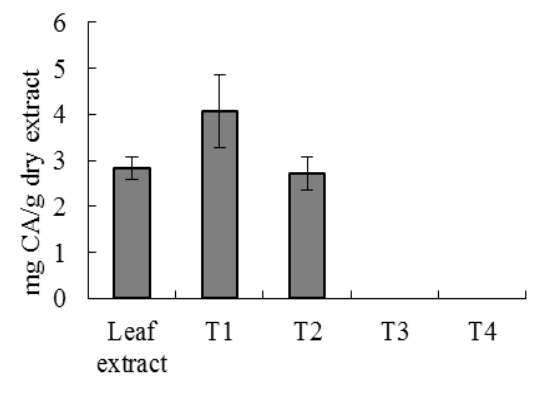

Figure 3. Quantification of caffeic acid content in callus and leaf extracts

Caffeic acid had been previously reported produced by plants and tissue culture of Artemisia genus. The production of caffeic acid was detected in aerial parts of $A$. minor (He et al. 2009); callus and suspension culture of $A$. absinthium (Ali et al. 2013); tea extract of A. annua L. (Carbonara et al. 2012; Suberu et al. 2014). In addition to caffeic acid, its derivatives are mainly consisting of $A$. annua as reported by (Carbonara et al. 2012; Suberu et al. 2014). In addition, the production of caffeic acid from other plants was reported from the tissue culture of Aronia melanocarpa (Szopa and Ekiert, 2014) and Sericostoma pauciforum (Jain et al. 2012).

As conclusion, this study suggested that the potential of tissue culture of A. апnиa on antioxidant activity. Callus treatment with combination of NAA + kinetin performed the best growth, however, combination NAA + BA showed the highest biological activities and caffeic acid content. It is considered that NAA promoted a good effect on callus growth, meanwhile, BA supported better effect on biological activities. Furthermore, the study revealed that caffeic acid was detected not only in leaf extract but also in callus extract particularly treatment 1 and 2 . Treatment 1 showed best combination of plant growth regulators showing in the increased level of both biological activities and caffeic acid production compared with the leaf extract of A. annua. 


\section{ACKNOWLEDGEMENTS}

We thank Tasaka Aya for her kind help during the study.

\section{REFERENCES}

Ahlawat S, Saxena P, Alam P, Wajid S, Abdin MZ. 2014. Modulation of artemisinin biosynthesis by elicitors, inhibitor, and precursor in hairy root cultures of Artemisia апnиa L. J Plant Interact 9 (1): 811-824.

Ali M., Abbasi BH., Haq I. 2013. Production of commercially important secondary metabolites and antioxidant activity in cell suspension cultures of Artemisia absinthium L. Ind Crops Prod 49: 400-406.

Amoo SO, Aremu AO, van Staden J. 2013. Shoot proliferation and rooting treatments influence secondary metabolite production and antioxidant activity in tissue culture-derived Aloe arborescens grown ex vitro. Plant Growth Regul 70: 115-122.

Baraldi R, Isacchi B, Predieri S, Marconi G, Vincieri FF, Bilia AR. 2008. Distribution of artemisinin and bioactive flavonoids from Artemisia аппиа L. during plant growth. Biochem Sist Ecol 36: 340-348.

Basma AA, Zakaria Z, Latha LY, Sasidharan S. 2011. Antioxidant activity and phytochemical screening of the methanol extracts of Euphorbia hirta L. Asian Pac J Trop Med 4: 386-390.

Carbonara T, Pascale R, Argentieri MP, Papadia P, Fanizzi FP, Villanova L, Avato P. 2012. Phytochemical analysis of a herbal tea from Artemisia annua L. J Pharm Biomed Anal 62: 79-86.

Cieśla Ł, Kowalska I, Oleszek W, Stochmal A. 2012. Free-radical scavenging activities of polyphenolic compounds isolated from Medicago sativa and Medicago truncatula assessed by means thinlayer chromatography DPPH' rapid test. Phytochem Anal 24: 47-52.

El-Haci IA, Bekkara FA, Mazari W, Gherib M. 2013. Phenolics content and antioxidant activity of some organic extracts of endemic medicinal plant Anabasis aretioides Coss. \& Moq. from Algerian Sahara. Phcog J 5: 108-112.

Ferreira JFS, Janick J. 1996. Distribution of artemisinin in Artemisia аппиа. In: Janick J (eds) Progress in new crops, ASHS Press, Arlington.

Han J, Ye M, Qiao X, Xu M, Wang BR, Guo DA. 2008. Characterization of phenolic compounds in the chinese herbal drug Artemisia annua by liquid chromatography coupled to electrospray ionization mass spectrometry. J Pharm Biomed Anal 47: 516-525.

Hashimoto NM, Genovese MI, Lajolo FM. 2005. Antioxidant activity of dietary fruits, vegetables and commercial frozen pulps. J Agric Food Chem 53: 2928-2935.

He ZZ, Yan JF, Song ZJ, Ye F, Liao X, Peng SL, Ding LS. 2009. Chemical constituents from the aerial parts of Artemisia minor. J Nat Prod 72: 1198-1201.
Ibrahim MH, Jaafar HZ, Karimi E, Ghasemzadeh A, 2012. Primary, secondary metabolites, photosynthetic capacity and antioxidant activity of the Malaysian Herb Kacip Fatimah (Labisia pumila Benth) exposed to potassium fertilization under greenhouse conditions. Intl $\mathbf{J}$ Mol Sci 13 (11): 15321-15342.

Jain SC, Pancholi B, Jain R. 2012. In vivo and in vitro phytochemical, microbial and antioxidant evaluation of Sericostoma pauciflorum Stocks ex Wight callus. Intl J Pharm Pharm Sci 4 (1): 332-336.

Jayaprakasha GK, Singh RP, Sakariah KK. 2001. Antioxidant activity of grape seed (Vitis vinifera) extracts on peroxidation models in vitro. Food Chem 73: 285-290.

Jelodar NB, Bhatt A, Mohamed K, Keng CL. 2014. Review: New cultivation approaches of Artemisia апnиа L. for a sustainable production of the antimalarial drug artemisinin. J Med Plant Res 8 (10): 441-447.

Keng CL, Singaran N, Lim BP. 2010. Production of artemisinin from cell suspension culture of Artemisia annua L. Asia Pac J Mol Biol Biotechnol 18 (1): 138-141.

Laughlin JC. 2002. Post-harvest drying treatment effects on antimalarial constituents of Artemisia annua L. Acta Hortic 576: 315-320.

Mohammad A, Alam P, Ahmad MM, Ali A, Ahmad J, Abdin MZ. 2013. Impact of plant growth regulators (PGRs) on callogenesis and artemisinin content in Artemisia annua L. plants. Indian J Biotechnol 13: 26-33.

Moyo M, Bairu MW, Amoo SO, van Staden J. 2011. Plant biotechnology in South Africa: micropropagation research endeavours, prospects and challenges. S Afr J Bot 77: 996-1011.

Nin S, Bennici A, Roselli R, Mariotti D, Schiff S, Magherni AR. 1997. Agrobacterium-mediated transformation on Artemisia absinthium L., (Wormwood) and production of secondary metabolites. Plant Cell Rep 16: 725-730.

Suberu JO, Canelon IR, Sullivan N, Lapkin AA, Barker GC. 2014. Comparative cytotoxicity of artemisinin and cisplatin and their interaction with chlorogenic acid in MCF7 breast cancer cells. Chem Med Chem 9: 2791-2797.

Szopa A, Ekiert H. 2014. Production of biologically active phenolic acids in Aronia melanocarpa (Michx.) Elliott in vitro cultures cultivated on different variants of the Murashige and Skoog medium. Plant Growth Regul 72: 51-58.

Weathers PJ, Arsenault PR, Covello PS, McMickle A, Teoh KH, Reed DW. 2011. Artemisinin production in Artemisia annua: studies in planta and results of a novel delivery method for treating malaria and other neglected diseases. Phytochem Rev 10 (2): 173-183.

Willcox M, Falquet J, Ferreira JFS, Gilbert B, Hsu E, Melilo de Magalhaes P, Plaizier-Vercammen J, Sharma VP, Wright CW. 2007. Artemisia annua as a herbal tea for malaria. Afr J Trad Complement Alternat Med 4: 121-123.

Zia M, Rehman R, Chaudary MF. 2007. Hormonal regulation for callogenesis and organogenesis of Artemisia absinthium L. Afr J Biotechnol 6 (16): 1874-1878 